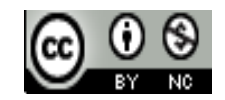

Journal of Education, Teaching, and Learning is licensed under

A Creative Commons Attribution-Non Commercial 4.0 International License.

\title{
THE MANAGEMENT OF FACILITIES AND INFRASTRUCTURE BASED ON MANAGEMENT INFORMATION SYSTEM APPLICATIONS FOR GOODS OWNED BY STATE (SIMAK-BMN)
}

\author{
Rumiari, Wahyudi, Muhammad Chiar \\ Universitas Tanjungpura, Pontianak, Indonesia \\ E-mail:rumiari_79@yahoo.co.id
}

\begin{abstract}
The management weakness of facilities and infrastructure in implementing the application of the State Property Management Information System (SIMAK BMN) is the cause of lack of optimal management of facilities or infrastructure or the application of SIMAK BMN by the school principal in empowering education staff and stakeholders within the madrasa. The purpose of this study was to describe the management of application-based infrastructure and State-Owned Management Information System (SIMAK BMN). The approach used in this study was qualitative research with a type of case study research. The stages in this study consisted of field, field and data processing. Data analysis takes place together with the process of collecting data, reducing data, presenting data, and drawing conclusions/verification. The results obtained in this study were (1) Planning of facilities and infrastructure made by madrasas provides an overview of the planning of needs achieved in the purpose of education; (2) Organizing application-based facilities and infrastructure SIMAK BMN in MTsN 1 Singkawang shoed a positive tendency to implement mechanisms, tasks and organizing functions that are conveyed to all teachers; (3) The implementation of SIMAK BMN application-based facilities and infrastructure at MTsN 1 Singkawang showed a tendency to be less than optimal; (4) Monitoring of application-based facilities and infrastructure SIMAK BMN at MTsN 1 Singkawang showed the tendency to carry out internal reconciliation, external reconciliation and pertangungjawban through semester reports. Therefore, it can be concluded, the management of facilities and infrastructure based on the application of the State Owned Management Information System (SIMAK BMN) at MTsN 1 Singkawang was an attempt to curb the recording of application-based infrastructure through the management of Property Management Information System functions. Country (SIMAK BMN).
\end{abstract}

Keywords: Management; Facilities; Infrastructure; Mangement Information System; Application

\section{INTRODUCTION}

Education is a direction for humans to grow according to what is in themselves and their environment. It should not be separated from good governance or management to improve the quality of education. Complete and integrated management that cannot be determined in order to achieve predetermined goals and can be realized effectively, efficiently, and together.

Muhammad Asif Sheikh (2010: 154) said that "Management is a process carried out by one or more individuals to coordinate the activities of others to achieve results, which cannot be achieved by just one individual." Antony R.N. and Govindarajan V (2018: 1) explains that "Management is an action procedure consisting of several vital functions, to get the goals of each company achieved through the efforts of its personnel." Different opinions with Mullins in Bernard Burnes (2004: 512) say that "management is science and art."

Whereas according to Murty (2007: 10) explains that "Management is art because there are definite management principles. This is also a science because by applying these principles, the predetermined goals can be achieved ". Management can be synthesized so that more than one person can be carried out together with principles that are in accordance with important functions to achieve the specified goals.

Mullins (2010: 433) states that "This gives us a description and summary of convenient managerial work as clarification of objectives, planning, organizing, directing and controlling." Knight and Willmott in Mullins (2010: 425). Explain that "refers to managing as a day-to-day activity that 
involves interaction between people who" are not related or totally different from other areas of life, except perhaps in the rhetoric and hype surrounding management." The above opinion explains the management of activities related to other people and carried out interaction through management functions of daily activities.

To manage management that both considers the skills or special skills of human resources, human resources, and knowledge to achieve educational success. According to Maswardi Muhammad Amin and Yuliananingsih (2016: 13) said that "management of education is a series in the implementation of education conducted by human resources or groups of people associated with activities, organizing, directing, coordinating and driving the delivery and delivery of human resources, resources and infrastructure, and financial resources to achieve educational goals ". Efforts can be made to make this happen through the provision of education through educational institutions and infrastructure.

According to Minister of National Education Regulation Number 24 of 2007 concerning standards for infrastructure and infrastructure that support educational standards and infrastructure for Elementary / Madrasah Ibtidaiyah (SD / MI), Junior High Schools / Madrasah Tsanawiyah (Middle School / MTs), and High Schools / Madrasah Aliyah (SMA / MA). The standards of facilities and infrastructure in Government Regulation Number 19 of 2005 Chapter VII article 42 are mentioned:

a. Every education unit must have equipment equipped with furniture, educational equipment, educational media, books, and other learning resources, consumables, and other equipment needed to support the learning process that is ready and developing.

b. Every education unit must have infrastructure that includes administrative space, library space, labor space, workshop room, production unit room, canteen room, resources and services, sports facilities, places of worship, places of faith, places of creation, and other spaces or places needed to support a regular and continuous learning process.

Educational facilities and infrastructure are part of activities to support the education unit. According to Matin and Fuad (2016: 4) explain that "to help improve the ability of school residents to manage educational facilities and infrastructure in schools, there needs to be a standard management of facilities and infrastructure (standardization of education facilities and infrastructure) that can be used as a guide for school residents in managing the facilities and infrastructure needed by the school ".

According to Cotts, Roper, and Payant (2010: 4) states that "The most recent definition of facility management is a profession that encompasses multiple disciplines to ensure the functionality of the built environment by integrating people, place, process, and technology." While Imam Gunawan and Benty (2017: 319) explained that "Management of educational facilities and infrastructure in schools is the process of utilizing all educational facilities and infrastructure in schools as a process of utilizing all the facilities and infrastructure owned by the school." Thus it can be synthesized the management of facilities and infrastructure is the result of the procurement process, and the affective and efficient utilization process that is owned by the school requires a standard guideline in managing facilities and infrastructure.

Management of facilities and infrastructure is very important in the education unit to improve the learning process and its development. Improved management of facilities and infrastructure lead to order in the management and inventory of state property obtained through legitimate income. In this case, the management of facilities and infrastructure is the obligation of a Ministry / government institution both educational institutions that can be accounted for their acquisition and use through financial reporting and reporting of goods at the treasury at educational institutions. The existence of facilities and infrastructure in the education unit is a state asset that is in the recording of state property.

In Law No. 1 of 2004 concerning State Treasury, it is stated that the treasury is the management and accountability of state finances, including investments and separated assets, which are stipulated in the APBN and APBD. Therefore management and accountability of facilities and infrastructure for state property is an inseparable part of the management and accountability of state finances through application-based.

This application system is to improve systematic understanding and control in the scope of duties and responsibilities as a work unit or madrasa in managing facilities and infrastructure. So that the presentation applied to the State Property Management Information System (SIMAK BMN) can be used as an obligation for preparing state property reports and checks and balances between the flow of money and the flow of goods. In addition, the State Property Management Information System (SIMAK BMN) brings together the concept of goods management with reporting for the purpose of accountability for the implementation of the State Budget in the form of a balance sheet (General Secretary of the Ministry of Religion, 2010: 2).

In general, synthesizing the importance of the management of facilities and infrastructure is state-owned goods that support educational services as an effort to improve control, inventory management of facilities and infrastructure or goods and accountability in the application of the State Property Management Information System (SIMAK BMN).

Seeing the reality in the field, researchers found a problem that occurred at MTsN 1 Singkawang Tsanawiyah Negeri 1 Madrasa Jalan Ratu Sepudak, Naram Sub-District, North MTsN 1 Singkawang Sub-District, MTsN 1 Singkawang City, West Kalimantan Province, based on the results of monitoring and reports submitted by the principal, Administration, and operators. (1) not optimal, especially maintenance of equipment and machinery, buildings and buildings, and other assets; (2) has not been carried out optimally, especially in the provision of codification of goods, arrangement of goods and use of goods; (3) the recording of facilities and infrastructure through the application of the State-Owned Financial Management and 
Information Information System (SIMAK-BMN) has not been optimal, especially the use, utilization, and deletion; (4) the lack of optimal reporting and supervision of facilities and infrastructure to support obtaining reasonable without exception (WTP) within the Ministry of Religion of the Republic of Indonesia.

Preliminary observations on the condition of MTsN 1 Singkawang at this time are concentrated on controlling state property assets which are the management of facilities and infrastructure as facilities and completeness of education that refers to minimum services.

To regulate the assets of MTsN 1 Singkawang carried out for one fiscal year obtained or the current fiscal year through a circular letter from the Director of BMN No. S-2/KN/2013 dated January 2, 2014, concerning notes on reports of state property. Therefore routine supervision is carried out, which includes all the facilities and infrastructure obtained from legitimate income. For timely and targeted reporting carried out for 2 semesters as accountable for the use of finance and goods.

The position of the use of facilities and infrastructure that belong to the state consists of land with an area of 3,200 m2 square which is controlled by Madrasah Tsanawiyah Negeri 1 MTsN 1 Singkawang and has been carried out to certify the land of ownership of the Ministry of Religion of the Republic of Indonesia. Equipment and machinery totaling 1,011 pieces owned by Madrasah Tsanawiyah Negeri 1 MTsN 1 Singkawang have been determined by User Status (PSP) by the Regional Office of the Ministry of Religion of West Kalimantan Province. The building and building obtained by the Madrasah Tsanawiyah Negeri 1 MTsN 1 Singkawang numbering 10 units have been carried out Determination of User Status (PSP) by the Ministry of Finance of the Republic of Indonesia as the manager of state property to users of state property whereas the Network and other fixed assets are controlled by MTsN 1 Singkawang which is registered as other state property, both intracomptable and extractive. The weak management of facilities and infrastructure in implementing the State-Owned Management Information System application (SIMAK BMN) is thought to be the cause of lack of optimal management of facilities or infrastructure or the application of SIMAK BMN by the school principal in empowering education staff and instructors in madrasah environments.

Based on this description the researcher is interested in studying in depth the management of facilities and infrastructure based on the application of the State Property Management Information System (SIMAK BMN) at MTsN 1 Singkawang, arguing that the management of facilities and infrastructure is a factor that determines the success of managing state and financial assets assuming if the management of facilities and infrastructure is good, then both financial and goods accountability managed by the madrasa, on the contrary, the existence of audit findings on financial and goods management has an effect on the performance of the madrasa which has declined, and no research with the same title has been held in madrasas.

\section{MethodOLOGY}

This study will describe the management of facilities and infrastructure based on the application of state property management information systems at MTsN 1 Singkawang. Based on the explanation above, this researcher uses a qualitative research approach. Researchers, in this case, participate directly in the field while conducting research, interviews, observations, and recording in detail about the findings in the study. This type of case study research uses in-depth interview techniques to explore more deeply or more detailed explanations of a phenomenon.

The presence of researchers is one of the important elements in qualitative research. Research planner, data collection, analysis, data interpreter, and eventually become the reporter of the results of his research. As well as in this study, researchers must be present in a direct location, because researchers act as the main instrument / key instrument in collecting data directly. The researcher must realize that he is a planner, the implementation of data collection and data analyzer as well as being the reporter of research results.

The main instrument of this research is the researcher himself. Using researchers as instruments have advantages and disadvantages. The advantage of researchers as instruments is that subjects are more responsive to their intentions; researchers can adjust to research settings. So that researchers can explore all parts of the research setting to collect data, decisions can be right, directed. While the weakness of researchers as instruments is to interpret data and facts, researchers are influenced by perceptions or impressions they have before data and facts are found. Likewise, in providing information, respondents are strongly influenced by perceptions and impressions of research.

In the process of selecting the informant, the researcher used a purposive technique, namely the researcher chose people who were considered to know clearly the problem being investigated. The presence of researchers in the field in order to dig up information, researchers used three stages, namely the selection of the initial informant, taking further informants, and stopping the selection of further informants. In the final stage, the researcher considers the research to have been completed, except when new information is found relating to the problems in the study. Thus researchers try to avoid the influence of the subject and maintain the environment naturally so that the social process that occurs goes as it should.

The location of this study took place at MTsN 1 MTsN 1 Singkawang Jalan Ratu Sepudak, Naram Sub-District, North MTsN 1 Singkawang District, MTsN 1 Singkawang. Because the focus of this research is the management of facilities and infrastructure in implementing the accounting and financial management information systems of state property, the subjects of the study are the Head of Madrasah, Head of Administration, Administrative Implementation Staff, and teachers who are given additional assignments as representatives the head of the madrasa and the documentation that relates to the focus of this research. 
In this study, using data obtained through observation, indepth interviews, and documentation, from informants who provide responses and questions provided. The data sources used in this study are: (1) Primary sources are data that directly provide data to researchers, regarding the opinions of informants about the management of application-based facilities and infrastructure SIMAK BMN in terms of planning, organizing, implementing, and monitoring. Data collection The elements in this research are direct researchers involved in participatory observation, with elements of informants consisting of Head of Madrasah, Administration, Operator SIMAK BMN, Waka Facilities, and Infrastructure, with guidelines prepared by researchers and carried out through triangulation at MTsN 1 Singkawang. (2) Secondary sources are sources of data that are not directly obtained by the researcher, in the form of supporting documents and data from primary data sources from observations or data collection regarding the management of application-based infrastructure and facilities SIMAK BMN at MTsN 1 Singkawang. Other elements in this study are related documents such as documents, institutional profiles, photographs, certificates, and other printed documents.

In this study, researchers used data collection techniques:

a. Interview

In the interview process, researchers are guided by the instruments made by previous researchers, and the results of interviews will be recorded by researchers. For media interviews, researchers use stationery and are equipped with cellphones to facilitate the results of interviews. Furthermore, in this study interviews or interviews were conducted by means of dialogue with the headmaster, facilities and infrastructure, administration, treasurers, and operators SIMAK BMN to obtain information about the management of facilities and infrastructure based on the questions that had been prepared.

Interviews in qualitative research are in-depth (in-depth interviews) because they want to explore information holistically and clearly from informants. In connection with research, researchers will conduct interviews with personal MTsN 1 Singkawang.

b. Observation

In this study, observations are needed to be able to understand the process of the interview, and the results of interviews can be understood in the context. Observations that will be made are observations on the subject, subject behavior during the interview, interacting with the researcher and the things that are considered relevant so they can provide data on the results of the interview.

The observation method used in this study is to obtain information by observing various things in the madrasa that are related to the management of facilities and infrastructure based on the application of state property management information systems (SIMAK BMN) to the head of the madrasah, facilities, and infrastructure, administration, treasurer and operator.

Observations are carried out according to a predetermined and scheduled schedule by researchers that can change according to the conditions of the researcher. The instruments used by researchers are observation guides, stationery, and schedules made by researchers. In observation activities, the researcher will try to balance the activities of the informant as it means that they do not place themselves as researchers who seem to be looking for data. But it really involves itself in every focus of research through communicators and as communicants.

c. Documentation Study

To obtain data on the management of facilities and infrastructure based on the application of state property management information systems (SIMAK BMN) through observation, the researchers tried to be in everyday situations at MTsN 1 Singkawang, mingling with the madrasa head, facilities and infrastructure, administration, treasurer and operator in understanding the process of planning, organizing, implementing, and supervising the management of facilities and infrastructure.

Therefore, this technique is a technique of collecting data by collecting and analyzing documents, both written, drawing, and electronic documents. Documents collected in accordance with the focus of the study. In relation to this research, the documents expected by the researcher are as follows:

1) Background of MTsN 1 Singkawang and Madrasah profile.

2) The physical condition of Madrasah facilities and infrastructure.

3) Documents on duties and functions of personnel related to the management of facilities and infrastructure in Madrasas.

4) Data on ownership of facilities and infrastructure that have been recorded in the SIMAK BMN application.

5) Letter on determining the status of the use of facilities and infrastructure from the side of the user of the goods.

6) Decree on responsibility for managing state property in Madrsah.

7) Photo documents as data acquisition from various other sources.

In the implementation of data, collection, researchers try to adjust themselves related to the ethics of researchers in the field in accordance with the considerations of the norms possessed by informants and convey the intentions or objectives subjectively.

Data analysis is an activity to organize, sort, group, give a code or sign, and categorize it so that a finding is based on the focus or problem that you want to answer. Through a series of activities, qualitative data that are usually scattered can be simplified to be easily understood. After the data collected is then analyzed. Data analysis takes place together with the process of collecting data, reducing data, presenting data, and drawing conclusions / verification.

Data collection Research with a qualitative approach, data analysis techniques carried out simultaneously with data collection. At least three data analysis activities carried out by Miles and Huberman in Sugiyono (2016: 91) can be described in Fig. 1. 


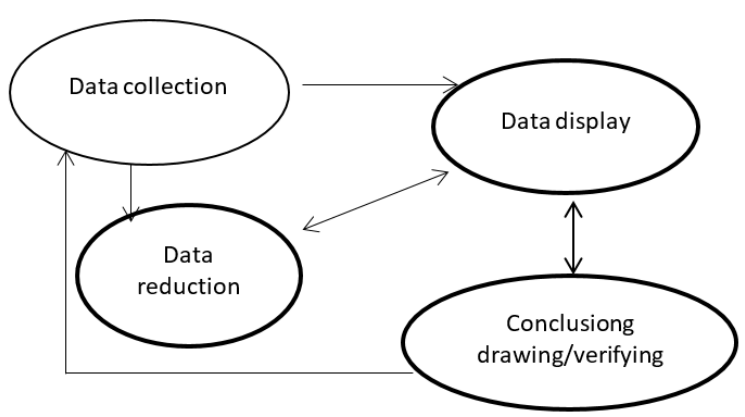

Fig. 1 Components in data analysis (Interactive model)

a. Data reduction

Data reduction means summarizing, choosing the main things, focusing on the important things, looking for themes and patterns. Thus the data that has been reduced will make it easier for researchers to collect further data, and look for it if needed. Data reduction can be assisted with electronic equipment such as minicomputers, by giving the code to certain aspects.

b. Data presentation.

In this step, the researcher presents data that has been reduced to tables, graphs, pie charts, pictograms, and the like. Through the presentation of the data, the data is organized, arranged in a pattern, so that it will be more easily understood.

c. Conclusion Drawing / Verification.

The third step is drawing conclusions and verification. The initial conclusions found are still temporary and will change if new strong evidence is found at the next stage of data collection. But if it turns out that the conclusions at the initial stage are supported by strong valid and consistent evidence when the researcher carries out the next stage of data collection, then the conclusions are those that are crystalline. Thus the conclusions in qualitative research may answer the problem formulation from the start, but it may not because the problem and the formulation of the problem in qualitative research are still temporary or a shadow problem and will develop after the research is in the field.

This study uses two validity findings techniques in data collection, namely First, Triangulation. The most widely used triangulation technique is through other sources. Triangulation with sources means comparing and checking the degree of trust in information obtained through different time and tools through qualitative methods. This can be achieved through (1) comparing observational data with interview data. (2) comparing what people say in public with what is said personally. (3) comparing what people say about the research situation to what they say all the time. (4) comparing a person's situation and perspective with various opinions and views of people such as ordinary people, middle-aged or high-educated people, people who are and government people and (5) comparing interviews with the contents of a related document. Secondly, member checks. Member check is the process of checking data obtained by researchers to the data giver. The technique is carried out by the researcher by showing and re-confirming the data that has been obtained previously to the same informant.

\section{Stage - Research Phase}

This research will be carried out in several stages or steps. The step of this study follows the steps written by Sujarweni (2014: 30), as follows:

a. Pre-Field
1) Arrange design
2) Select field
3) Take care of licensing
4) Explore and assess the situation
5) Select and utilize informant
6) Prepare instruments
7) Ethical issues in the field

b. Field
1) Understand and enter the field
2) Data collection
3) Data Processing
4) Data reduction
5) Display data
6) Take conclusions and verification
7) Final conclusion.

\section{RESULTS AND DISCUSSION}

\section{A. Results}

Management of application-based facilities and infrastructure The State-Owned Management Information System (SIMAK BMN), applies aspects namely planning, organizing, implementing and monitoring and presenting the application of the State-Owned Management Information System (SIMAK BMN). Based on the results of observations and interviews supported by documentation, the research findings can be conveyed as follows:

1. Application-based facility and infrastructure planning SIMAK BMN.

Based on the results of data analysis research on planning facilities and infrastructure at MTsN 1 Singkawang, there are several findings in the study as follows:

a. Vision and Strategic

1) Interview Results

From the results of interviews with the head of the madrasa and the head of administration, the facilities and infrastructure for the MTsN 1 Singkawang state that the vision and strategy were prepared jointly by the state property management team based on conditions and inputs from various parties. Vision and strategy were disseminated together with the teacher council meeting, as stated in the accountability report of the MTsN 1 Singkawang accountability. This vision and strategy are made as a reference in the management of state property now and in the future.

2) Documentation Results

Based on the documentation obtained in relation to the vision and strategic management of facilities 
and infrastructure planning regarding reports on the accountability of the performance of the MTsN 1 Singkawang.

b. Annual Activity Plan and Madrasah Strategic Plan

1) Interview results

Based on the results of interviews with the head of the madrasa, the head of administration and the infrastructure facilities that at the MTsN 1 Singkawang was informed about the annual work plan and madrasah strategic plan. The annual work plan and strategic plan are prepared by the madrasa by involving the madrasah committee within the stipulated period. In the preparation and presentation of the annual work plan and the strategic plan made to deliver the progress of the madrasa in the specified time and improve the quality of education services as contained in national education standards. The mechanism for preparing the work plan is made separately in order to facilitate the delivery of an effective direction.

2) Documentation Results

Based on the results of documentation about the annual work plan and strategic plan for MTsN 1 Singkawang can be seen from the print out of the RKAK/L application.

c. Mechanism of Planning Facilities and Infrastructure

1) Interview Results

Based on interviews with the head of the madrasa and the head of the administration, information was obtained that the mechanism for the preparation of facilities and infrastructure planning at MTsN 1 Singkawang was based on the needs needed by the madrasa. For example, it is necessary to procure operational deficiencies in madrasah quality improvement related to nonsupporting material sources such as building space and buildings, equipment and machinery and supporting teaching and learning activities. The drafting process was supported by the Region Office of the Ministry of Religion of West Kalimantan through a planned budget for madrasah activities. Plans compiled to be submitted in the budget user questionnaire during the fiscal year of MTsN 1 Singkawang.

2) Documentation Results

The results of documentation on the mechanism for the preparation of facilities and infrastructure for MTsN 1 Singkawang can be seen in the form of a fraction out of the SAIBA application, the use of the budget.

Based on the results of the interview, the results of the documentation and the results of observations about the planning of application-based infrastructure and facilities SIMAK BMN madrasa tendencies already have a vision and strategic plan for the management of state property that is prepared based on the objectives to be achieved. In formulating objectives have met the needs of madrasas to improve quality than planned.

The objectives to be achieved are in the annual program work plan and madrasah strategic plan which is prepared jointly with the head of the madrasa, administration, teachers, and the madrasa committee. Besides that, the planning of facilities and infrastructure can also be carried out by the mechanism of planning the planning of facilities and infrastructure through the proposal of madrasah needs in the current fiscal year.

2. Organizing application-based facilities and infrastructure SIMAK BMN

Based on the results of research data analysis on organizing facilities and infrastructure in MTsN 1 Singkawang, there are several findings in the study as follows:

a. Organizational structure

1) Interview results

Organizational structures created by madrasas are used to facilitate the implementation of work and achieve the targets set. In organizing that is made involves structural and functional personnel through direct appointment from the head of administration. Functional staff is teachers who are given additional assignments by the headmaster. The head of the madrasa as the top manager at the madrasa with Kewenagan directly appoints employees to occupy the job description with input from the head of administration.

2) Documentation results

The documentation results on the organizational structure of facilities and infrastructure management at MTsN 1 Singkawang.

b. Organizing tasks and functions

1) Interview Results

Division of tasks and functions is the decision of the head of the madrasa to fulfill the responsibility of the education administration services that have been determined. There is a need for direction and input from the head of administration to carry out these duties and functions. In addition to dividing the work according to each task and function that has been divided, grouped according to subactivities and coordinated in carrying out it.

Based on the results of interviews with the head of the madrasa, head of administration, infrastructure facilities, and operators, said that MTsN 1 Singkawang that the organizational structure in the madrasah has been made in accordance with their respective duties and functions based on the ability and competence possessed by the employee on the assignment. Tasks and functions are made in order to fulfill the analysis of employee positions related to the performance they perform and gret position in the office. Division of tasks and functions can be explained through the position of the position in the description of the duties and activities of each. 
In organizing that is made involves structural and functional personnel through direct appointment from the head of administration. Functional staff is teachers who are given additional assignments by the headmaster.

2) Documentation Results

Based on the results of interviews and the results of documentation about organizing facilities and infrastructure in MTs 1, MTsN 1 Singkawang already has an organizational structure in the management of facilities and infrastructure. The organizational structure created in accordance with the tasks and functions in the structure of the structure that is made. The mechanism in organizing is made by paying attention to the ability of staff competencies to understand and operationalize the applications used. The head of the madrasa in the organizational structure holds a policy on the facilities and infrastructure used. The duties and functions of each have been carried out in accordance with the instructions and obligations that refer to the assignment document in the form of a decision letter from the head of the madrasa about the appointment of the state property management team and the additional assignment of teacher positions. Organizing is followed up with employee performance reports and semester reports on managing state property.

3. Implementation of application-based infrastructure and facilities SIMAK BMN

Based on the results of research data analysis on the implementation of facilities and infrastructure at MTsN 1 Singkawang, there are several findings in the study as follows:

a. Form the mechanism and process of implementing facilities and infrastructure

1) Interview Results

Based on the results of interviews with the head of the madrasa, head of administration, infrastructure facilities and operators about the form of mechanisms for the implementation of facilities and infrastructure, information was obtained that the forms and mechanisms for the implementation of facilities and infrastructure were carried out jointly by the management team in accordance with the decision letter from the madrasa head.

The forms and mechanisms that are made are based on the needs and preparation of madrasa facilities and infrastructure that are set in the annual program plan and madrasah strategic plan through meetings with the teacher council. The process of implementing facilities and infrastructure is carried out in accordance with the duties and functions of each of the personnel that has been determined.

This process related to the procurement, maintenance, inventory, and elimination of infrastructure facilities that are recorded as state property has not been carried out optimally due to limitations in the supervision and security of infrastructure by human resources.

2) Documentation Results

Based on the results of documentation on the form and mechanism of the implementation of facilities and infrastructure at MTsN 1 Singkawang.

b. Availability of application systems

1) Interview Results

The success of the process of recording facilities and infrastructure is inseparable from the support of an adequate application system, and the latest up-to-date data has been carried out. Based on the results of interviews and documentation of infrastructure facilities and operators SIMAK BMN that the implementation of facilities and infrastructure in the recording is done through the application system, namely the SIMAK BMN application. The recording process is carried out through the stages of data input, data processing, and output data in the form of data information.

Data input is carried out after the information data has been collected, which has been done by manual documentation or data evidence. While the process of data after the data is input in the system through user commands in accordance with the menus presented. The data put out in question is the result of a series of data input and data processing. The results of the interview found that inputting data with the applied menus was found to have results of data information not in accordance with existing data pacts manually, and this is because the data documents do not match the reference data applied. The findings of the report on state property reports (BMN Candidates) were carried out at MTsN 1 Singkawang to overcome this discrepancy.

2) Documentation Results

The results of documentation and supporting data about the availability of application systems in the data collection of facilities and infrastructure.

Based on the results of interviews and documentation results found a tendency to be less than optimal in carrying out the process of procurement, maintenance, inventory, and elimination of uniform infrastructure can already carry out manual data recording that will be carried out input in computerizing data systematically within the application but not in accordance with the data system information produced.

Data was obtained by considering the yield with the limit price set in the recording of SIMAK BMN. After recording all facilities and infrastructure that become state property, it can be documented by the operator in the framework of checking the functional apparatus. 
SIMAK BMN is applied, the operator has updated the application, namely the compatibility of the latest database and reference according to the functions in the menus presented in computer software. If in recording a system error occurs, this is caused by the application not being updated with new data. Then the results obtained in the implementation of recording facilities and infrastructure in the form of documents as reports of computerized activities include goods balance sheet, list of goods, and transaction of goods acquisition. Report made by the operator in the form of a backup of data and semester reports in writing that is disclosed in the report of the user of state property at MTsN 1 Singkawang.

4. Monitoring of application-based infrastructure and facilities SIMAK BMN

Based on the results of data analysis research on the supervision of facilities and infrastructure in MTsN 1 Singkawang, there are several findings in the study as follows:

a. Availability of the program

1) Interview Results

Supervision carried out in madrasas is internal and external as a guarantee of success in the implementation of facilities and infrastructure. Internal supervision refers to supervision carried out by the school, while external supervision is carried out by other parties that require data on the implementation of facilities and infrastructure that are state assets. Based on interviews with principals and facilities, and operators were informed that MTsN 1 Singkawang as manager of state property had been carried out internally and externally. Internal supervision of the school principal through a program of reconciliation of the management of facilities and infrastructure in the madrasa. While the external supervision of the madrasa submits a report on the management of state assets that are controlled by the madrasa to other parties, namely the party that uses state assets through supervision and control of state assets (Wasdal).

2) Documentation Results

The results of the documentation and supporting data about the availability of the program are produced in a report.

b. Form of monitoring mechanisms and processes

1) Interview results

The form of monitoring and process mechanisms carried out in the madrasah is the provision of motivation and improvement in delivering reports on facilities and infrastructure in order to improve the ability of the role of employees in carrying out their work. Based on the results of interviews and observations, information was obtained that the form of the mechanism and monitoring process had been carried out by the head of the madrasah towards the facilities and operators SIMAK BMN who was also the manager of state property. Next, in the supervision process, data collection on facilities and infrastructure is carried out in accordance with the monitoring schedule carried out in the semester. Thus in the process, it is supported by the availability of applications in monitoring by e-registration or online.

Based on the results of interviews and the tends to positive observations that are the findings in this study, the study is in the form of reporting the use of state property carried out through internal reconciliation, external reconciliation, and end of semester reports in accordance with specified procedures and schedules. Internal reconfiguration supervision is an adjustment of data in the SIMAK BMN application (item flow) recording with the SAIBA (cash flow) application. This means that internal reconciliation sees the existence of financing obtained from the use of the budget on capital expenditure.

Internal reconciliation applies at the work unit level or at MTsN 1 Singkawang, which is valid at the end of the semester or the period of June 30 and December 31 in the current fiscal year. Then supervision in the form of external reconciliation is carried out at the level of the managing unit and user of state property. This supervision looks at the extent to which the work unit or madrasa uses the recorded state assets in the application submitted. This means that this reconciliation involves the supervision of other agencies that have the authority to supervise state property, namely the State Wealth and Auction Service Office (KPKNL) in MTsN 1 Singkawang.

Another supervision carried out by MTsN 1 Singkawang provides reports to parties that have interests both in software or data backup and written hardware, which is the result of system management processes in the application. Information on these data is the accountability of saker or madrasa in the management of facilities and infrastructure that are state assets.

\section{B. Discussion}

In this section, researchers discuss the results of research to obtain meaning from each formula contained in the research objectives. This discussion is based on conclusions and theoretical perspectives on the management of facilities and infrastructure based on the application of state property management information systems (SIMAK BMN).

1. Application-based facility and infrastructure planning SIMAK BMN

Planning is an activity that depicts beforehand things that will be done in order to achieve the stated goals. In this case, the planning is intended to design a vision and strategy, an annual activity plan, an annual strategic plan, a mechanism for preparing program objectives and 
formulating a work program. Thus the planning of application-based infrastructure and facilities SIMAK $\mathrm{BMN}$ can be defined is the process of achieving the program objectives that have been determined.

Based on the results of observations and interviews supported by documentation, it can be concluded that the SIMAK BMN application-based facility and infrastructure planning in formulating the vision and strategic plan, annual activity plan, annual strategic plan, program objectives and determining the state-owned goods management team are conducted through the headmaster meeting, head administration, board of teachers, and staff. Planning is based on input and suggestions from meeting participants in formulating the objectives and programs achieved.

According to Hikmah (2011: 101) said that "Educational planning is an activity related to efforts to form an educational program which includes everything that will be implemented, the determination of educational goals, policies in education, direction to be taken in educational activities, procedures, and methods which will be followed in an effort to achieve goals ". This means that the planning made by the madrasa provides an overview of the planning of needs achieved in the purpose of education. Prepared needs planning can be selfalized in the current budget year in accordance with the conditions allocated.

According to Government Regulation Number 27 of 2014 concerning Management of State Property, it is stated that needs planning is an activity to formulate the details of State / Regional Property Requirements to connect the procurement of past goods with the current situation as a basis for future actions.

Furthermore, the Minister of Finance Decree Number 311 / KM.6 / 2015 concerning the State-Owned Needs Planning Module, for the preparation of plans for the needs of State Property. Planning of state property needs is intended as a process of evaluating the relationship between the needs of state property in accordance with the programs and activities of Ministries / Institutions with the availability of BMN guided by the Ministry of Industry / Institutional Strategic Plan (K / L Strategic Plan) and Goods Standard Standard of Needs. Thus planning needs that are prepared are facilities and infrastructure that become state property to support the education process and education administration.

According to Daryanto and Farid $(2013 ; 106)$ stated that "Education facilities are all equipment, materials, and furniture directly used in the education process at school." This means that the educational facilities planned by the madrasa from the beginning are basic needs in the madrasa / school to assist in the education process. Meanwhile, according to Fauzan $(2016 ; 77)$ said that "Educational infrastructure is a facility that indirectly supports the educational process such as school buildings, sports fields, schoolyards, and so on." This means that educational infrastructure as a compliment in the education process is used indirectly. Thus the facilities and infrastructure planned by the madrasa either directly or indirectly as a supporter of education in the madrasa.

2. Organizing facilities and infrastructure-based applications SIMAK BMN

The activity of organizing facilities and infrastructure is an effort to achieve success in carrying out the tasks and functions achieved. Organizing is made, of course seeing the capabilities and competencies possessed by personnel to carry out tasks according to the job description given.

Based on the results of interviews and the results of the documentation of organizing facilities and infrastructure, a positive tendency has been carried out in accordance with the organizational structure, mechanisms, tasks and organizing functions delivered to all teachers. Another tendency that can be taken from organizing facilities and infrastructure increases staff competency and the ability of teachers to be given additional tasks in determining their duties and functions.

Organizational structure can be interpreted as a formal framework of an organization with a framework in which work tasks are divided, grouped, and coordinated by Robbins and Coulter (2007: 284), organizational structure in organizing facilities and infrastructure in MTsN 1 Singkawang forms a committee in accordance with position and position. The organizational structure is stipulated in the Decree of the Authorization of Goods Users of MTsN 1 Singkawang Number: 06 Year 2019 Regarding the Appointment of the Facilities and Infrastructure Management Team of MTsN 1 Singkawang consisting of the head of the madrasah as the responsibility, head of business as coordinator of facilities and infrastructure, general staff as operators at the same time user application SIMAK BMN, and Teacher (additional assignments) as facilities and infrastructure.

Mechanisms and tasks in organizing facilities and infrastructure in MTsN 1 Singkawang refer to tasks and positions that are in the analysis of the position of manager of state property. Description of tasks and activities in the form of 1) the head of the madrasa prepares BMN materials and equipment in accordance with applicable procedures and provisions so that the implementation of the work can run well; 2) the head of business checks the material for managing $\mathrm{BMN}$ in accordance with his field of work so that in the implementation there is conformity with the original plan; 3) operators SIMAK BMN controls BMN management in accordance with applicable procedures and provisions so that there are no irregularities in the implementation, as well as coordinating with parties and units related to funds to know other agencies in order to implement them to achieve optimal results; 4) facilities and infrastructure compile reports on the results of the implementation of tasks in accordance with applicable procedures as material for evaluation and accountability. Mechanisms and tasks are the results of grouping and placement in accordance with the responsibility for the purpose of ignition. 
According to Masyhud (2014: 30) said that "Organizing can be interpreted as the whole process of grouping and placing people, tools, tasks, responsibilities, and authorities that exist within the organization so as to create an organizational system that can be mobilized as a unity in order to achieve goals that have been determined effectively and efficiently ". The purpose of the above opinion in organizing the madrasas provides an opportunity for individuals to carry out their duties and functions in accordance with their creativity in working. However, this is supported by material resources that have been declared as equal in the use of state property and are adequate as a means of achieving goals.

According to Government Regulation Number 27 of 2014 concerning Management of State Property Article 15 reads the state / regional property can be determined for the implementation of basic tasks and functions of state ministries / regional unit work units, to be operated by other parties in order to carry out public services the main tasks and functions of the state ministries / institutions of the work unit of the relevant regional apparatus.

On the other hand, the Minister of Finance Regulation No. 96 / PMk.06 / 2007 concerning Procedures for the Implementation of Use, Utilization, Removal and Transfer of State Property, states that the use of BMN to carry out basic tasks and functions is based on the determination of the use of goods so that the User will become the Ministry of Religion's main work on assets it acquires, (Ministry of Religion, General Secretary 2010: 73). Therefore, in the use of state property must be determined the status of its use in order to support the tasks and functions in the madrasa.

3. Implementation of application-based infrastructure and facilities SIMAK BMN

Implementation of facilities and infrastructure is a process that involves the ability of human resources and material resources in achieving predetermined goals. Implementation function in setting goals seen from the achievements and aspects that support these activities.

Based on the results of interviews and the results of documentation about the implementation of facilities and infrastructure, it shows a tendency to be less than optimal in implementing the mechanism, implementation process and availability of systems for processing data, documents, application system updates, data input, and reports on the data processing that is conveyed to all parties. Processing data through the data system process is used as a source of data information that is carried out by data transfer at the regional level as the responsibility in managing state property.

This answer is an implementation of evidence that the work unit or madrasa has carried out data processing through an application that regulates the order of administration of state property. Control of facilities and infrastructure is carried out for two periods or semesters in one year.
In accordance with the provisions in the Minister of Finance Regulation Number 246 / PMK.06 / 2014 concerning Procedures for Implementing the Use of State Property, Article 6 (1) reads as follows: Minister of Finance as Property Manager has the authority and responsibility; b) determine the status of the Use of BMN to be operated by another party; c) provide BMN temporary use approval; d) determine decisions / give approval over status Use of BMN; and e) supervise and control the implementation of the Use of BMN.

According to Siagian (2014: 17) states that "One way that is now commonly used in this connection is to create a master data (database) in which all types of information expected to be needed by all components of the company are stored and maintained." Furthermore, Deni Darmawan and Fauzi (2013: 101) explained that "The database (or database) is a systematic collection of computers so that it can be checked using a computer program to obtain information from the database."

Data processing system is needed that provides information that is suitable for the purpose and achievement in the time specified to obtain data from the information presented. Murty (2007: 29) explains that "A system is a set of interconnected and inter-related elements or component parts to achieve certain goals. A system has three significant parts.

The above opinion states that the system is mutually binding on several other components to achieve certain objectives that have been set. Then the system is a group of elements integrated with the same goal to achieve goals (Mc Leod in Deni Darmawan and Fauzi, 2013: 4). Thus MTsN 1 Singkawang in the implementation of facility-based facilities and infrastructure must be processed data through a data-based system as providing information on the intended purpose.

4. Monitoring of application-based facilities and infrastructure SIMAK BMN

Supervision is an action for control in correcting and preventing the tendency that is not in accordance with the stated objectives. Supervision of facilities and infrastructure can be carried out at the beginning and at the end of ongoing activities. Thus supervision in the activities of facilities and infrastructure to see the extent to which the implementation and provisions have been set.

Based on the results of the interviews and the results of documentation on supervision of facilities and infrastructure, the tendency has been to implement the availability of programs, the form of mechanisms and processes of supervision through internal reconciliation, external reconciliation, and responsibility through semester reports. The mechanism in internal and internal reconciliation is in accordance with the technical instructions in the SIMAK BMN application. This reconciliation provides an overview of the addition, development, and deletion of state property recorded in data management that has been inputted in the application system. 
According to Terry (2009: 18) states that "supervision includes the continuation of the task to see whether activities are carried out according to plan". In accordance with Government Regulation Number 27 of 2014 concerning Management of State/Regional Property, Part Two Supervision and Control of Article 75 paragraph (3) states that Authorities of goods users and goods users can request functional supervisors to conduct follow-up audits of monitoring and control results as referred to in paragraph (1) and paragraph (2). Then in the Circular of the Directorate General of State Wealth (DJKN) Number: $\mathrm{S}-2 / \mathrm{KN} / 2014$, the follow-up monitoring and evaluation of depreciation of user goods reported in 2013. Further regulated in PMK-244/PMK.06/2012 concerning Implementation Procedures Supervision and Control of State Property Article 24 paragraph (1) states that the Authorization of goods users makes an annual report on the results of supervision and control of State Property.

Based on PMK 102/PMK.05/2009 concerning Procedures for Reconciliation of State Property in the framework of Preparation of Financial Statements, it is mandated the importance of the reconciliation of State Property $(\mathrm{BMN})$ data. BMN reconciliation is the process of matching BMN value reports between two or more processing units to the same document source.

$\mathrm{BMN}$ reconciliation is carried out in order to produce mutually agreed data and BMN values based on Ministry/Institution data, data from the Directorate General of State Assets (DJKN) and data from the Directorate General of Treasury (DJPB). With the BMN reconciliation, it is expected that differences in records that have an impact on the accuracy and validity of the data presented in the $\mathrm{BMN}$ report and financial reports can be minimized.

Regulation of the Minister of Finance of the Republic of Indonesia Number 171/Pmk.05/2007 concerning Central Government Accounting and Financial Reporting System that Reconciliation is the process of matching financial transaction data that is processed with several different systems/subsystems based on the same source document. Furthermore, in Part Six Management Information Systems and Accounting for State Property In order to ensure the reliability of BMN values in the Balance Sheet with BMN reports, UAKPB conducts internal reconciliation with UAKPA.

The form of external reconciliation is in accordance with the Regulation of the Minister of Finance of the Republic of Indonesia Number 171/Pmk.05/2007 that LBKPS as referred to in paragraph (1) accompanied by Notes on BMN Reports along with ADK BMN transactions submitted to UAPPB-W/UAPPB-E1 and State Wealth Service Offices and Auction (KPKNL) every semester. LBKPT is accompanied by a Report on the Condition of the Goods, and a Note on the BMN Report submitted to UAPPB-W/UAPPB-E1 and KPKNL every year. UAKPB reconciles BMN reports with KPKNL every semester.
Article 40 of the Regulation of the Minister of Finance of the Republic of Indonesia Number 171/Pmk.05/2007, in order to maintain the continuity of the preparation and reliability of BMN/balance sheet reports, each SIMAK$\mathrm{BMN}$ organization has the authority to supervise and monitor the implementation of SIMAK-BMN in its working area. The report and supervision have been carried out as evidenced by a statement of responsibility by a work unit or madrasa.

Statement of Responsibility of State Ministries/Institutions Article 67 Statement of Responsibility as referred to in paragraph (1) contains a statement that the management of the APBN has been carried out based on an adequate internal control system and financial accounting has been prepared in accordance with the Standards Government Accounting.

\section{CONCLUSIONS AND SUGGESTIONS}

\section{A. Conclusions}

Based on the research findings and discussion of the results in the previous section, in general, this study can be concluded as follows:

1. Application-based infrastructure and infrastructure planning SIMAK BMN at MTsN 1 Singkawang showed a tendency to formulate program objectives and determine the state-owned goods management team through the headmaster's meeting, head of administration, the board of teachers, and staff. Planning is based on input and suggestions from meeting participants in formulating the objectives and programs achieved. planning made by the madrasa provides an overview of the planning of needs achieved in the purpose of education.

2. Organizing application-based facilities and infrastructure SIMAK BMN at MTsN 1 Singkawang showed a positive tendency to implement mechanisms, tasks, and organizing functions that are conveyed to all teachers. Other trends that can be taken from organizing facilities and infrastructure improve staff competency and the ability of teachers to be given additional duties in determining their duties and functions in determining the status of the use of state property.

3. The implementation of SIMAK BMN application-based facilities and infrastructure at MTsN 1 Singkawang showed that is not optimal in carrying out data processing, documents, application system updates, data input, and reports on the results of data processing that are submitted to all parties. Processing data through the data system process is used as a source of data information that is carried out by data transfer at the regional level as the responsibility in managing state property. This answer is an implementation of evidence that the work unit or madrasa has carried out data processing through an application that regulates the order of administration of state property.

4. Monitoring of application-based facilities and infrastructure SIMAK BMN at MTsN 1 Singkawang showed the tendency to carry out internal reconciliation, 
external reconciliation, and responsibility through semester reports. The mechanism in internal and internal reconciliation is in accordance with the technical instructions in the SIMAK BMN application. This reconciliation provides an overview of the addition, development, and deletion of state property recorded in data management that has been inputted in the application system.

\section{B. Suggestions}

In accordance with the research formulation, the results of the results and conclusions presented above, then some suggestions that need to be conveyed related to the management of application-based infrastructure and State Property Management Information System (SIMAK BMN) in MTsN 1 Singkawang State MTs as follows:

1. Application-based infrastructure and infrastructure planning SIMAK BMN should be written in writing the program objectives and development as well as determining the state-owned goods management team transparently. The program objectives and development can be renewed every budget year in accordance with the madrasa strategic plan.

2. Organizing application-based facilities and infrastructure SIMAK BMN should pay attention to the mechanisms, tasks and organizing functions that refer to the applicable provisions and staff competencies and the ability of the teacher to the tasks they carry out. Job duties and functions need to be made clear job descriptions in accordance with the performance contract contained in the employee performance goals.

3. Implementation of application-based infrastructure and facilities SIMAK BMN should be prepared for information gathering every month for processing data, documents, application system updates, data input, and reports on the results of data processing that are submitted to all parties. In processing data, there needs to be a more vigorous effort by the operator to coordinate with the partners on the registration that is applied, which is still experiencing obstacles when operating the system.

4. Application-based supervision of facilities and infrastructure SIMAK BMN should involve accrual ambassadors from the Office of the Ministry of Religion of MTsN 1 Singkawang optimally in evaluating internal reconciliation, external reconciliation, and responsibility through semester reports. Evaluation is carried out by examining the report notes that are made periodically and implementing monitoring in overcoming the final preparations for the semester and the end of the year.

\section{REFERENCES}

Amin, M.M, \& Yuliananingsih, M. (2016). Manajemen Mutu Aplikasi Dalam Bidang Pendidikan, Yogyakarta: Media Akademi.

Antony, R.N \& Govindarajan, V. (2018). Management Control System, Bangalore: Rai Technology University.
Burnes, B., (2004). Managing Change, England: Pearson Education.

Cotts, G.D. Roper, K.O. \& Payant, R.P. (2010). The Facility Management Handbook, United States of America: Amacom.

Darmawan, D \& Fauzi, K.N. (2013). Sistem Informasi Manajemen. Bandung: Remaja Rosdakarya Offset.

Daryanto, \& Farid, M. (2013). Konsep Dasar Manajemen Pendidikan Di Sekolah, Yogyakarta: Gava Media.

Fauzan. (2016). Pengantar Sistem Administrasi Pendidikan. Yokyakart: UII Press.

Gunawan, I. \& Benty, D.D.N. (2017). Manajemen Pendidikan Suatu Pengantar Praktik. Bandung: Alfabeta.

Hikmah. (2011). Manajemen Pendidikan. Bandung: Pustaka Setia.

Masyhud, M.S. (2014). Manajemen Profesi Kependidikan. Yogyakarta: Kurnia Kalam Semest.

Mullins, L.J. (2010). Management \& Organisational Behaviour, Englan : Pearson Education.

Murty, NSR. (2007). Management Principles and Practice, Excel Books Private Limited: Bharathiar University.

Matin \& Fuad, N. (2016). Manajemen Sarana dan Prasarana. Jakarta: Raja Grafindo Persada.

Peraturan Menteri Pendidikan Nasional Nomor 24 Tahun 2007 tentang Standar Sarana dan Prasarana, Jakarta: Menteri Pendidikan Nasional.

Robbins \& Coulter. (2007). Pengertian Struktur Organisasi, http://www.infodanpengertian.com/2015/04/pengertianstruktur-organisasi-menurut.html (Accessed May 1, 2019).

Sekretaris Jenderal. (2010). Petunjuk Teknis SIMAK-BMN, Jakarta: Kementerian Agama RI.

Siagian, S.P. (2014). Sistem Informasi Manajemen. Jakarta: Bumi Aksara.

Sujarweni, V.W. (2015). Sistem Akuntasi. Yokyakarta: Pustaka Baru Press.

Sugiyono. (2016). Metode Penelitian Kuantitatif, Kualitatif, dan $R \& D$. Bandung: Alfabeta.

Terry, G.R. (2009). Prinsip-Prinsip Manajemen. Transleted by J.Smith D.F.M. Jakart : Bumi Aksara.

Undang-Undang Nomor 1 Tahun 2004 tentang Perbendaharaan Negara. 2004. Jakarta. 